\title{
U.S. International Transactions in 2002
}

Steven B. Kamin, of the Board's Division of International Finance, prepared this article. Faith E. Darling provided research assistance.

After slightly narrowing during the cyclical slowdown of 2001, the U.S. current account deficit widened in 2002, as it had over the previous decade. Two-thirds of the increase in the deficit last year was attributable to an increase in the deficit for trade in goods and services. In addition, net investment income receded as receipts from abroad declined more than payments on foreign investments in the United States.

Most of the rise in the trade deficit in 2002 was the result of an increase in the value of imported goods and services. Imports had declined sharply in the previous year in response to the slowdown in U.S. economic activity, and as activity accelerated in 2002 , imports reversed much of their earlier decline. Although the pace of expansion also began to pick up in the economies of the United States' foreign trading partners last year, the value of U.S. exports declined for the second year in a row, albeit to a much smaller extent than in 2001. ${ }^{1}$ These movements caused the

1. In fact, as discussed below, although the value of exports for 2002 as a whole was below its 2001 level, exports actually rose from the fourth quarter of 2001 to the fourth quarter of 2002 . deficit in goods and services to rise to $\$ 436$ billion in 2002 (table 1).

A swing in the balance on investment income, from a $\$ 21$ billion surplus in 2001 to a $\$ 5$ billion deficit in 2002, reflected primarily a decline in net direct investment income. Increases in the profitability of foreign direct investment in the United States last year helped to boost payments to foreigners above the abnormally low levels of 2001. Receipts on U.S. direct investment abroad were held back by continued economic slack and low profits in many foreign economies. The deficit in portfolio income rose very slightly but would have increased considerably more were it not for the low levels of interest rates at home and abroad.

The record $\$ 503$ billion current account deficit registered in 2002 was also a record as a share of GDP- 4.8 percent (chart 1). The counterpart of this deficit was a $\$ 474$ billion surplus in the financial account balance, an increase of $\$ 92$ billion over the 2001 financial account surplus. The rise in the surplus was attributable primarily to stepped-up foreign official purchases of U.S. assets; changes in the components of private capital flows largely offset each other. The statistical discrepancy in the U.S. international accounts also rose.

An implication of the large U.S. current account deficits in recent years has been that, taken together,

1. U.S. international transactions, 1998-2002

Billions of dollars except as noted

\begin{tabular}{|c|c|c|c|c|c|c|}
\hline Item & 1998 & 1999 & 2000 & 2001 & 2002 & $\begin{array}{l}\text { Change, } \\
\text { 2001-02 }\end{array}$ \\
\hline $\begin{array}{l}\text { Trade in goods and services, net } \\
\text { Goods, net } \\
\text { Services, net } \ldots \ldots \ldots \ldots \ldots \ldots . . . . . . . . .\end{array}$ & $\begin{array}{r}-167 \\
-247 \\
80\end{array}$ & $\begin{array}{r}-262 \\
-346 \\
84\end{array}$ & $\begin{array}{r}-379 \\
-452 \\
74\end{array}$ & $\begin{array}{r}-358 \\
-427 \\
69\end{array}$ & $\begin{array}{r}-436 \\
-484 \\
49\end{array}$ & $\begin{array}{l}-77 \\
-57 \\
-20\end{array}$ \\
\hline $\begin{array}{l}\text { Investment income, net } \\
\text { Compensation of employees, net } \\
\text { Unilateral current transfers, net }\end{array}$ & $\begin{array}{r}13 \\
-5 \\
-45\end{array}$ & $\begin{array}{r}24 \\
-6 \\
-49\end{array}$ & $\begin{array}{r}28 \\
-6 \\
-53\end{array}$ & $\begin{array}{r}21 \\
-6 \\
-49\end{array}$ & $\begin{array}{r}-5 \\
-6 \\
-56\end{array}$ & $\begin{array}{r}-26 \\
0 \\
-7\end{array}$ \\
\hline Current account balance & -204 & -293 & -410 & -393 & -503 & -110 \\
\hline $\begin{array}{l}\text { Official capital, net } \\
\text { Private capital, net }\end{array}$ & $\begin{array}{r}-27 \\
91\end{array}$ & $\begin{array}{r}55 \\
210\end{array}$ & $\begin{array}{r}36 \\
373\end{array}$ & $\begin{array}{r}0 \\
382\end{array}$ & $\begin{array}{r}93 \\
381\end{array}$ & $\begin{array}{r}94 \\
-1\end{array}$ \\
\hline Financial account balance & 64 & 265 & 409 & 382 & 474 & 92 \\
\hline Capital account balance & 1 & -3 & 1 & 1 & 1 & $\mathbf{0}$ \\
\hline Statistical discrepancy & 139 & 31 & 0 & 11 & 29 & 18 \\
\hline $\begin{array}{l}\text { MeM2 } \\
\text { Current account as percent of GDP }\end{array}$ & -2.3 & -3.2 & -4.2 & -3.9 & -4.8 & -.9 \\
\hline
\end{tabular}

NoTE. Here and in the following tables, components may not sum to totals because of rounding.

1. Percentage point êhinge. 
1. U.S. external balances, 1970-2002

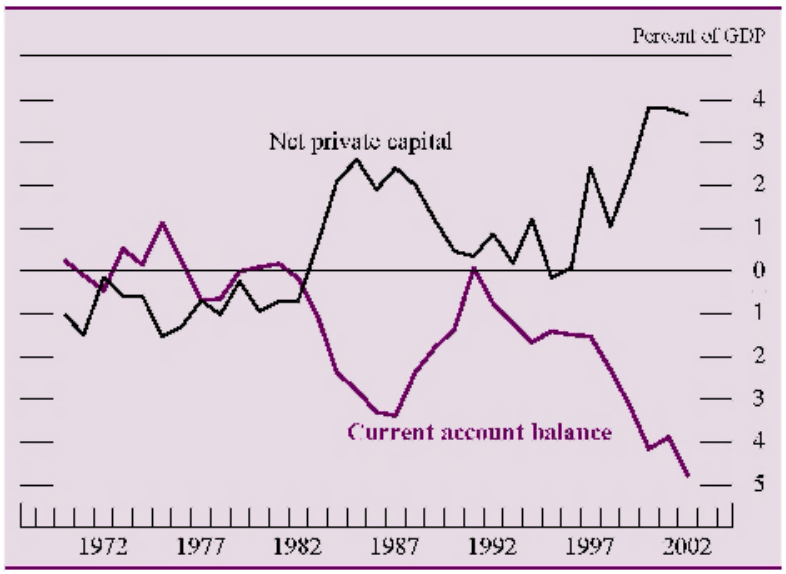

NotE. The data are annual.

SOURCE. U.S. Department of Commerce, Bureau of Economic Analysis (BEA).

the economies of the rest of world have been running a current account surplus (see box "The Foreign Counterpart to the U.S. Current Account Deficit").

\section{MAJOR ECONOMIC INFLUENCES ON. U.S. INTERNATIONAL TRANSACTIONS}

Several factors had a significant influence on U.S. international transactions in 2002: the emergence of the U.S. and foreign economies from the cyclical slowdown in 2001, increases in the prices of oil and other primary commodities, the reversal of the dollar's appreciating trend, and movements in real returns at home and abroad.

\section{U.S. Economic Activity}

After remaining unchanged during 2001, U.S. real GDP increased 2.9 percent between the fourth quarter of 2001 and the fourth quarter of 2002 (table 2). Economic conditions turned up notably during the first half of the year. Household spending on both personal consumption items and housing remained solid, businesses curtailed their inventory liquidation and began to raise spending on some types of capital equipment, and private employment began to edge higher. For the first half of 2002, real GDP grew 3.1 percent at an annual rate.

However, the momentum of the recovery diminished somewhat as the year progressed. Concerns about corporate governance weighed on financial markets, and a rise in international tensions boosted oil prices and exacerbated uncertainties already faced by businesses about the economic outlook. By midsummer, stock prices had declined, risk spreads widened, and liquidity eroded in corporate debt markets. These developments, combined with a high degree of underlying caution on the part of businesses, contributed to continued weak capital spending. With for-

2. Change in real GDP in the United States and abroad, 1999-2002

Percent, annual rate

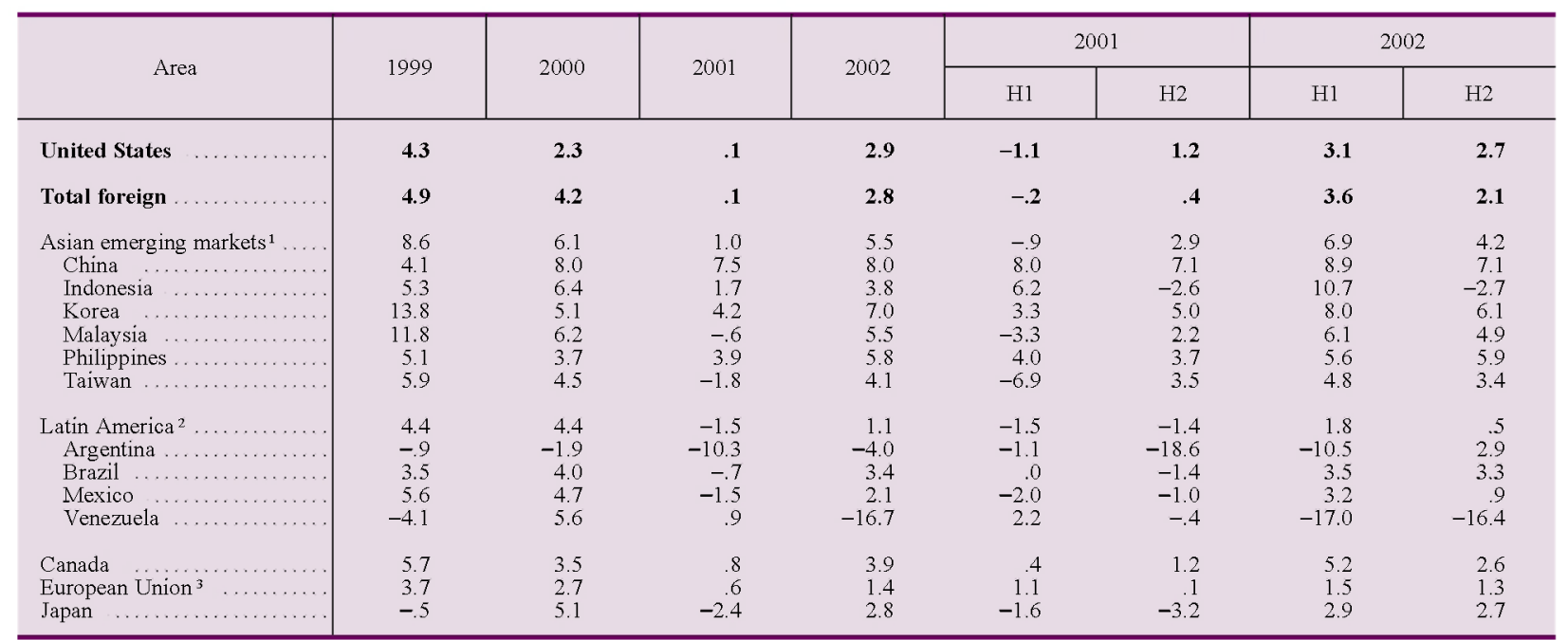

NotE. Aggregate measures are weighted by moving bilateral shares in U.S. exports of merchandise. Annual data are four-quarter changes. Half-yearly data are calculated as $\mathrm{Q} 4 / \mathrm{Q} 2$ or $\mathrm{Q} 2 / \mathrm{Q} 4$ changes at an annual rate.

1. Weighted average of China, Hong Kong, Indonesia, Korea, Malaysia, Philippines, Singapore, Taiwan, and Thailand.

2. Weighted average of Argentina, Brazil, Chile, Colombia, Mexico, and

3. Member countries are Austria, Belgium, Denmark, Finland, France, Germany, Greece, Ireland, Italy, Luxembourg, the Netherlands, Portugal, Spain, Sweden, and the United Kingdom.

SoUrCE. Various national sources; Federal Reserve seasonal adjustments in some cases. Venezuela. 


\section{The Foreign Counterpart to the U.S. Current Account Deficit}

The counterpart of the current account deficit in the United States is an aggregate current account surplus in the rest of the world. Current account balances are influenced by a variety of factors that differ from country to country, and those of foreign economies exhibit quite diverse movements as the U.S. current account changes. In the 1980s, during the last large run-up in the U.S. current account deficit, much of the imbalance was matched by current account surpluses in the economies of the European Union (EU) and Japan. For example, in 1987, the U.S. current account deficit reached $\$ 161$ billion, or 3.4 percent of GDP, while the EU countries and Japan recorded current account surpluses of $\$ 28$ billion and $\$ 85$ billion respectively (chart A). This state of affairs was broadly consistent with the importance of these two areas in U.S. trade at the time: Together, the EU countries and Japan accounted for about 40 percent of U.S. exports and imports. It was also consistent with the especially marked rise in the foreign exchange value of the dollar against the currencies of those countries in the mid-1980s.

The most recent rise in the U.S. current account deficit has been associated with a distribution of counterpart surpluses abroad that differs somewhat from the 1980s pattern. As in the mid-1980s, Japan is running a surplus, although at about $\$ 110$ billion last year it is only moderately larger than in 1987, even as the U.S. deficit is currently about three times as large as it was then. The European Union's surplus last year was only about $\$ 50$ billion, a small counterpart to the U.S. deficit. Conversely, the Asian emerging-market economies, whose share of U.S. imports has risen from about 16 percent in the mid-1980s to about 24 percent more recently, ran a current account surplus of nearly $\$ 120$ billion in 2002, a considerably larger balance than they

A. Current account balances, United States, Japan, and the European Union, 1975-2002

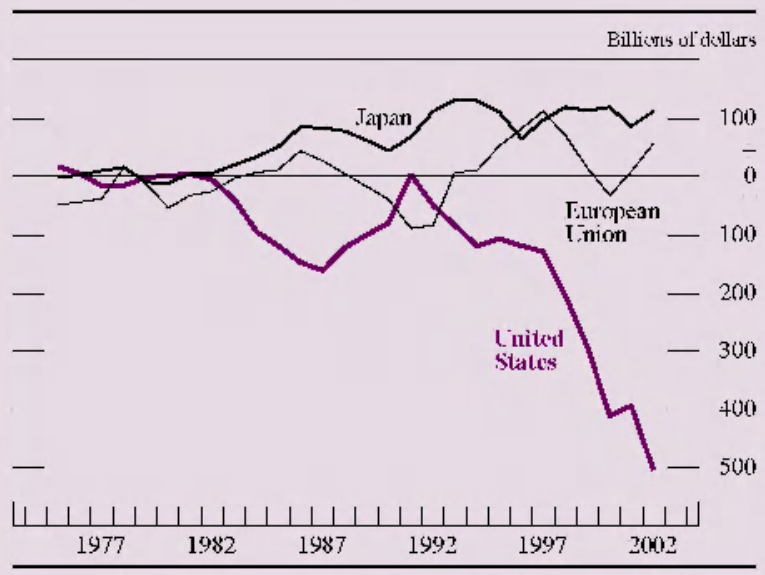

NoTE. The data are annual. For membership of the European Union, see note 3 of table 2 in the main text. The European Union balance is calculated as the sum of the balances of individual European Union countries.

Source. BEA; International Monetary Fund (IMF), World Economic Outlook database. recorded in the mid-1980s (chart B). Finally, the largest single counterpart to the U.S. imbalance is the global statistical discrepancy, which is the negative of the sum of the world's current accounts (chart C). In principle, the world's current accounts should sum to zero, but because of statistical problems and misreporting of payments and receipts, the statistical discrepancy is generally not zero and can sometimes be quite large. Increases in oil revenues earned by countries whose international transactions are not well reported, along with rising cross-border holdings of assets (returns on which also are frequently underreported), may explain some of the growth of the discrepancy in recent years.

B. Current account balances, United States and Asian emerging markets, 1975-2002

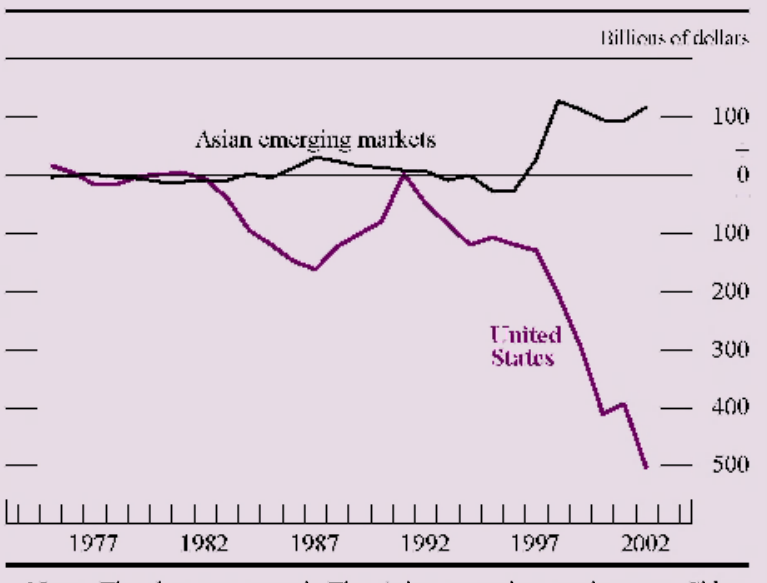

NOTE. The data are annual. The Asian emerging markets are China, Hong Kong, Indonesia, Korea, Malaysia, Philippines, Singapore, Taiwan, and Thailand. For 2002, balances for some Asian economies are estimates.

SOURCE. BEA; IMF, World Economic Outlook database.

C. U.S. current account balance and aggregate statistical discrepancy for all countries, $1975-2002$

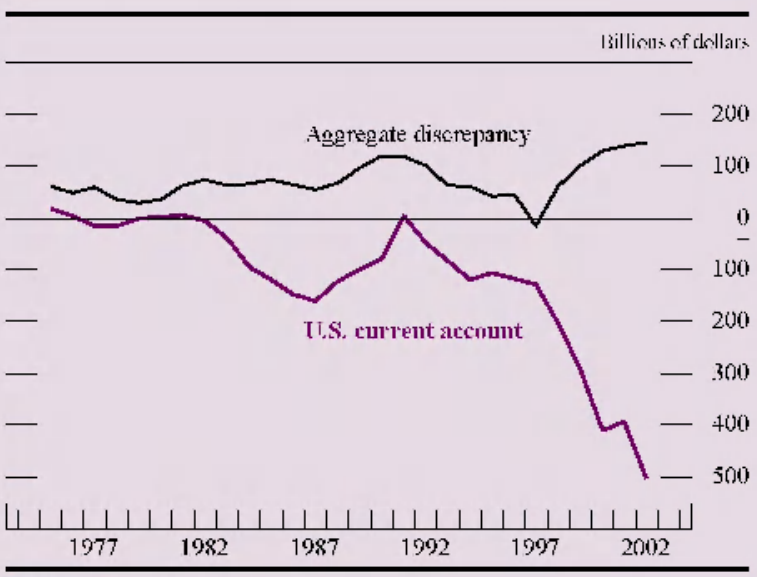

NotE. The data are annual.

SOURCE. BEA; MMF, World Economic Outlook database. 
eign demand for U.S. products weakening as well, manufacturers trimmed production during the fall. Employment in the private sector declined again, and the unemployment rate moved up, reaching 6 percent in December. For the second half of 2002, the growth of real GDP declined to 2.7 percent at an annual rate, and for the fourth quarter it was only 1.4 percent.

\section{Foreign Economic Activity}

After a pronounced slowdown in 2001, economic activity accelerated in the economies of U.S. trading partners in 2002 as it did in the United States. Higher growth abroad reflected a number of factors, including monetary and fiscal stimulus, reductions in the pace of inventory liquidation, and the effect of increasing economic activity in the United States. The pickup in growth abroad, as in the United States, was concentrated in the first half of last year, as a strong rally in the high-tech exporting economies of emerging-market Asia was joined by robust growth in Canada and, to a lesser extent, Mexico. Growth in other regions-including the euro area and South America-remained subdued. As the U.S. economy decelerated in the second half, the pace of recovery slowed in Asia and Canada, while performance remained lackluster in much of the rest of the world.

The Canadian economy registered the strongest performance among the major foreign economies last year despite some slowing in the second half. Its strength reflected robust growth of consumption and residential construction as well as an end to inventory runoffs early in the year. As a net oil exporter, Canada has also benefited from the high level of oil prices, and because it is less dependent on high-tech production than is the United States, it likewise suffered less from the on-going weakness in that sector.

The Japanese economy grew during 2002, although the pace of growth was barely enough to offset the decline in output that took place in 2001. Japanese growth was driven mainly by exports, with smaller contributions coming from increased consumption and a slower pace of inventory reduction. However, private investment spending and conditions in labor markets remained weak, and deflation continued.

Economic performance in the euro area was quite sluggish last year. Although exports were up, growth in consumption was modest, and private investment declined. Economic weakness was especially pronounced in some of the larger countries-Germany, Italy, and, to a lesser extent, France-while growth in some of the smaller euro-area countries was more robust.
In the emerging-market economies last year, economic performance diverged considerably between Asia and Mexico, on the one hand, and the rest of Latin America, on the other. The Asian emergingmarket economies generally performed well in 2002; they were led, as in previous years, by China, where real GDP again expanded more than 7 percent. Of the other emerging Asian economies, Korea recorded the strongest growth. The economy grew more rapidly in the first half of the year, when global demand for high-tech products rose most quickly and domestic demand (especially consumption) surged; growth slowed in the second half of the year as global high-tech demand weakened and tensions over North Korea intensified. Other economies in the region, including some of the larger Southeast Asian economies and Taiwan, also exhibited strong performance in the first half of 2002 followed by some weakening of growth in the second.

One of the few bright spots in Latin America last year was the Mexican economy - boosted by the U.S. recovery, its growth was moderate for the year as a whole despite some late slowing. Conversely, much of South America was beset by adverse economic, financial, and political developments. In Brazil, economic activity managed to expand in 2002, despite considerable financial volatility surrounding the October presidential election. Argentine GDP contracted further in 2002 after declining 10 percent in 2001, although financial and economic conditions appeared to stabilize in the second half of the year. Output plunged in Venezuela in the midst of extreme economic and political turmoil, including a coup attempt in April and a national strike declared in December.

\section{Primary-Commodity Prices}

Oil prices began 2002 at less than $\$ 20$ per barrel for West Texas intermediate (chart 2), having declined considerably in the previous year amidst widespread economic weakness. Much of the decline occurred after the events of September 11, 2001, in response to a fall in jet fuel consumption, weaker economic activity, and reassurances of stable supply from Saudi Arabia. However, oil prices began rising again in February and March of 2002 in response to both improving global economic activity and a productionlimiting agreement among OPEC and some major non-OPEC producers. As a consequence of this agreement, actual production declined, albeit not to the extent implied by the agreed limits. Heightened tensions in the Middle East, along with severe politi- 
2. Oil prices, $1986-2002$

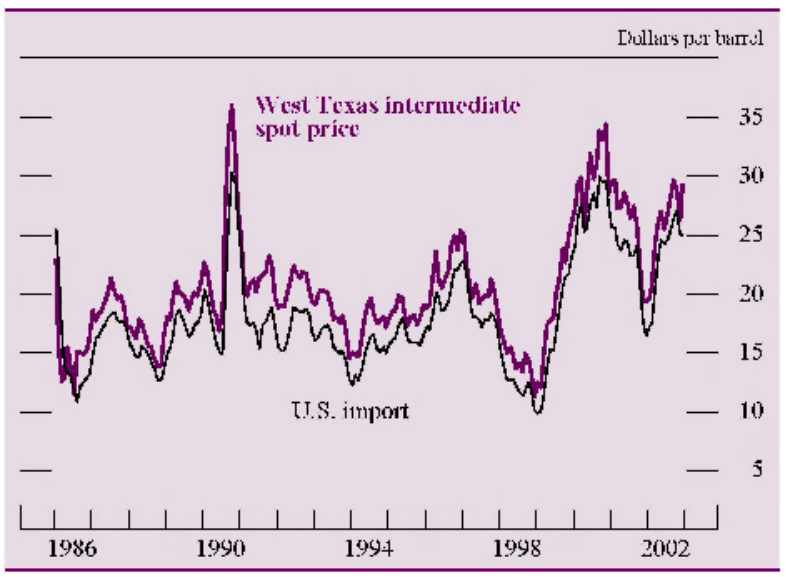

NoTE. The data are monthly.

SOURCE. Wall Street Journal; BEA.

cal turmoil in Venezuela, also put upward pressure on oil prices. A strike in Venezuela, which began on December 2, 2002, caused already meager crude oil inventories in the United States to fall to levels not seen since the 1970 s; the reduced inventories exacerbated the effect of the reduced production on oil prices.

Prices of nonfuel primary commodities (chart 3) also picked up somewhat last year after falling steadily throughout much of 2001. Most of the increase in prices reflected decreases in supply. Adverse weather in many parts of the world reduced harvests and sent prices of several agricultural commodities-wheat, soybeans, and cottonsoaring, albeit from very depressed levels. Also, cocoa prices rose because of a civil war in Ivory

3. Price of world nonfuel primary commodities, 1993-2002

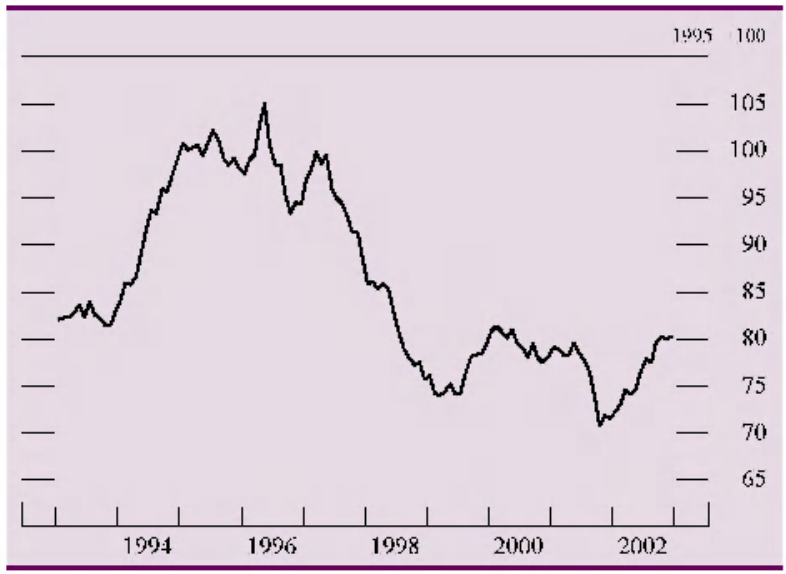

NoTE. The data are monthly. The price shown is a weighted average of forty-five prices.

SOURCE. IMF, International Financial Statistics, index of nonfuel primary commodity prices in dollars.
Coast, which produces a substantial fraction of the world's cocoa. Production restraint by copper producers led to a slight gain in the price of that commodity. Finally, the price of gold shot up more than 20 percent last year, most likely in response to heightened global tensions.

\section{U.S. Price Competitiveness}

Changes in the price competitiveness of U.S. export and import-competing industries last year were primarily the result of changes in the foreign exchange value of the dollar, as well as relative movements in inflation rates at home and abroad. The price-adjusted broad dollar index is a measure of the foreign exchange value of the dollar in terms of the currencies of the United States' principal trading partners, adjusted for relative movements in U.S. and foreign inflation rates. Having appreciated substantially since the mid-1990s, the broad real dollar index extended its mild upward trend into the early part of 2002 (chart 4). However, the dollar weakened sharply in late spring and early summer amid deepening concerns about U.S. corporate governance and profitability. Around that time, market analysts also appeared to become more worried about the growing U.S. current account deficit and its potential negative influence on the future value of the dollar. After strengthening a bit around midyear as growth prospects for other major economies appeared to dim, the broad real dollar index dropped again late in the year as geopolitical tensions intensified; it registered a $1 \% / 4$ percent decline for the year as a whole.

\section{Foreign exchange value of the U.S. dollar, 1990-2002}

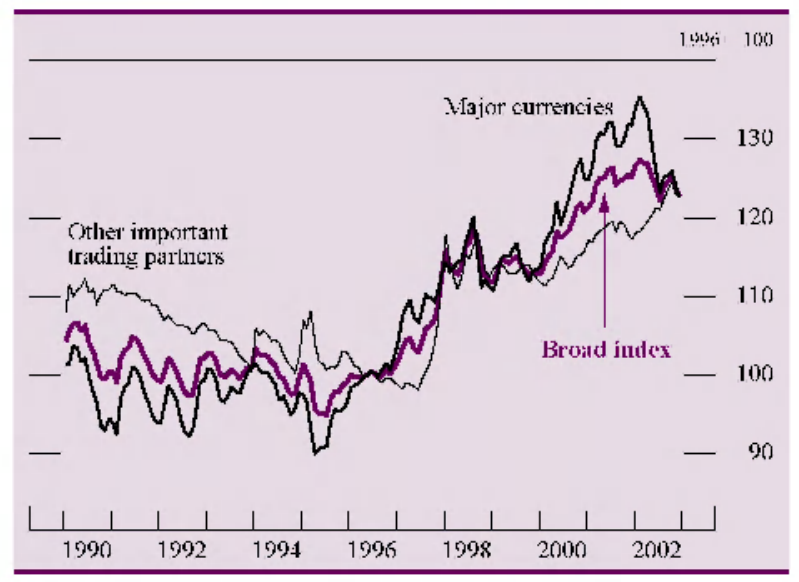

Note. The data are monthly. Each data series is a price-adjusted index of foreign currency units per dollar. The broad index covers a large group of important U.S. trading partners. The major currencies index covers the currencies that are widely traded in international financial markets. 
In 2002, the dollar depreciated against all of the major currencies - those currencies that trade widely in international financial markets - but the magnitude of these declines varied. The dollar showed particular weakness against the euro; the dollar's decline of 16 percent more than reversed a substantial portion of its rise against the euro in the preceding couple of years. The dollar declined about 10 percent against the yen last year. Relative to the Canadian dollar, however, the U.S. dollar declined only 1 percent on balance.

Even as the dollar declined 7 percent on a priceadjusted basis against the major currencies last year, it appreciated $4 \frac{1}{2}$ percent against a weighted average of the currencies of other U.S. trading partners. This appreciation occurred despite a decline in the dollar against the currencies of Asian emerging-market economies and is accounted for almost entirely by a rise of the dollar against the Mexican peso.

\section{DEVELOPMENTS IN U.S. TRADE IN GOODS AND SERVICES}

The U.S. trade deficit in goods and services, having narrowed significantly in 2001, widened in 2002 and thereby resumed its trend of the past decade (table 3 ). The $\$ 77$ billion expansion of the trade deficit last year reflected a $\$ 51$ billion rise in the nominal value of imports and a \$26 billion reduction-the second annual decline - in exports.

Movements in the annual totals of exports and imports from 2001 to 2002, however, obscure important movements of these trade figures over the course of last year. Nominal exports of goods and services hit their recent low in the fourth quarter of 2001 and then recovered substantially in the second and third quarters of 2002 before reversing some of these gains in the fourth quarter (chart 5). Hence, while the average value of exports in 2002 was below its 2001 level, owing to its very depressed level at the start of

3. U.S. international trade in goods and services, 2000-2002

Billions of dollars except as noted

\begin{tabular}{|c|c|c|c|c|c|c|c|}
\hline \multirow{2}{*}{ Item } & \multirow{2}{*}{2000} & \multirow{2}{*}{2001} & \multirow{2}{*}{2002} & \multicolumn{2}{|c|}{ Change } & \multicolumn{2}{|c|}{$\begin{array}{l}\text { Percent change, } \\
200 \mathrm{I}-02\end{array}$} \\
\hline & & & & $2000=01$ & 2001-02 & Year over year & Q4 to Q4 \\
\hline Balance (exports less imports) & -379 & -358 & -436 & 20 & -77 & $\ldots$ & $\ldots$ \\
\hline Exports & 1,064 & 998 & 972 & -66 & -26 & -3 & 5 \\
\hline $\begin{array}{l}\text { Services } \\
\text { Goods }\end{array}$ & $\begin{array}{l}292 \\
772\end{array}$ & $\begin{array}{l}279 \\
719\end{array}$ & $\begin{array}{l}289 \\
683\end{array}$ & $\begin{array}{l}-13 \\
-53\end{array}$ & $\begin{array}{r}10 \\
-36\end{array}$ & $\begin{array}{r}4 \\
-5\end{array}$ & $\begin{array}{r}14 \\
2\end{array}$ \\
\hline $\begin{array}{l}\text { Capital equipment } \\
\text { Aircraft and parts } \ldots \ldots \ldots \ldots \ldots \\
\text { Computer equipment } 1 \ldots \ldots \ldots \ldots \\
\text { Semiconductors } \ldots \ldots \ldots \ldots \ldots \\
\text { Telecommunications equipment } \\
\text { Other machinery and equipment }\end{array}$ & $\begin{array}{r}357 \\
48 \\
56 \\
60 \\
31 \\
162\end{array}$ & $\begin{array}{r}322 \\
53 \\
48 \\
45 \\
28 \\
149\end{array}$ & $\begin{array}{r}291 \\
51 \\
39 \\
42 \\
22 \\
137\end{array}$ & $\begin{array}{r}-35 \\
5 \\
-8 \\
-15 \\
-3 \\
-13\end{array}$ & $\begin{array}{r}-31 \\
-2 \\
-9 \\
-3 \\
-6 \\
-12\end{array}$ & $\begin{array}{r}-10 \\
-4 \\
-19 \\
-6 \\
-20 \\
-8\end{array}$ & $\begin{array}{r}-1 \\
-1 \\
-7 \\
5 \\
-13 \\
0\end{array}$ \\
\hline $\begin{array}{l}\text { Industrial supplies ............ } \\
\text { Automotive vehicles and parts } \\
\text { Consumer goods ............. } \\
\text { Foods, feeds, and beverages ....... } \\
\text { Other ................................ }\end{array}$ & $\begin{array}{r}173 \\
80 \\
89 \\
48 \\
25\end{array}$ & $\begin{array}{r}160 \\
75 \\
88 \\
49 \\
24\end{array}$ & $\begin{array}{r}157 \\
78 \\
84 \\
50 \\
23\end{array}$ & $\begin{array}{r}-12 \\
-5 \\
-1 \\
2 \\
-1\end{array}$ & $\begin{array}{r}-3 \\
3 \\
-4 \\
0 \\
-1\end{array}$ & $\begin{array}{r}-2 \\
4 \\
-4 \\
0 \\
-5\end{array}$ & $\begin{array}{l}8 \\
4 \\
1 \\
2 \\
3\end{array}$ \\
\hline Imports & 1,443 & 1,356 & 1,407 & -87 & 51 & 4 & 14 \\
\hline $\begin{array}{l}\text { Services } \ldots \ldots \text {. } \\
\text { Goods } \ldots \ldots . .\end{array}$ & $\begin{array}{r}219 \\
1,224\end{array}$ & $\begin{array}{r}210 \\
1,146\end{array}$ & $\begin{array}{r}240 \\
1,167\end{array}$ & $\begin{array}{r}-8 \\
-78\end{array}$ & $\begin{array}{l}30 \\
21\end{array}$ & $\begin{array}{r}14 \\
2\end{array}$ & $\begin{array}{l}19 \\
13\end{array}$ \\
\hline $\begin{array}{l}\text { O11 } \\
\text { Non-oil } \ldots \ldots \ldots \ldots \ldots \ldots \ldots\end{array}$ & $\begin{array}{r}120 \\
1,104\end{array}$ & $\begin{array}{r}104 \\
1,042\end{array}$ & $\begin{array}{r}104 \\
1,063\end{array}$ & $\begin{array}{l}-17 \\
-62\end{array}$ & $\begin{array}{r}0 \\
21\end{array}$ & $\begin{array}{l}0 \\
2\end{array}$ & $\begin{array}{l}46 \\
10\end{array}$ \\
\hline $\begin{array}{l}\text { Capital equipment } \\
\text { Aircraft and parts } \ldots \ldots \ldots \ldots \ldots \\
\text { Computer equipment }{ }^{1} \ldots \ldots \ldots \ldots \\
\text { Semiconductors } \ldots \ldots \ldots \ldots \ldots \\
\text { Telecommunications equipment } \\
\text { Other machinery and equipment }\end{array}$ & $\begin{array}{r}347 \\
26 \\
90 \\
48 \\
33 \\
150\end{array}$ & $\begin{array}{r}298 \\
31 \\
74 \\
30 \\
25 \\
138\end{array}$ & $\begin{array}{r}284 \\
26 \\
75 \\
26 \\
23 \\
134\end{array}$ & $\begin{array}{r}-49 \\
5 \\
-16 \\
-18 \\
-8 \\
-12\end{array}$ & $\begin{array}{r}-14 \\
-6 \\
1 \\
-4 \\
-1 \\
-4\end{array}$ & $\begin{array}{r}-5 \\
-18 \\
2 \\
-14 \\
-6 \\
-3\end{array}$ & $\begin{array}{r}5 \\
-17 \\
8 \\
6 \\
18 \\
6\end{array}$ \\
\hline $\begin{array}{l}\text { Industrial supplies ............. } \\
\text { Automotive vehicles and parts } \\
\text { Consumer goods ........... } \\
\text { Foods, feeds, and beverages } \\
\text { Other }\end{array}$ & $\begin{array}{r}182 \\
196 \\
282 \\
46 \\
51\end{array}$ & $\begin{array}{r}173 \\
190 \\
284 \\
47 \\
51\end{array}$ & $\begin{array}{r}166 \\
204 \\
308 \\
50 \\
52\end{array}$ & $\begin{array}{r}-9 \\
-6 \\
2 \\
1 \\
-1\end{array}$ & $\begin{array}{r}-7 \\
14 \\
23 \\
3 \\
1\end{array}$ & $\begin{array}{r}-4 \\
7 \\
8 \\
7 \\
2\end{array}$ & $\begin{array}{r}12 \\
11 \\
16 \\
10 \\
1\end{array}$ \\
\hline
\end{tabular}

1. Computers, accessories, peripherals, and parts. Not applicable. 
5. U.S. imports and exports, $2000-2002$

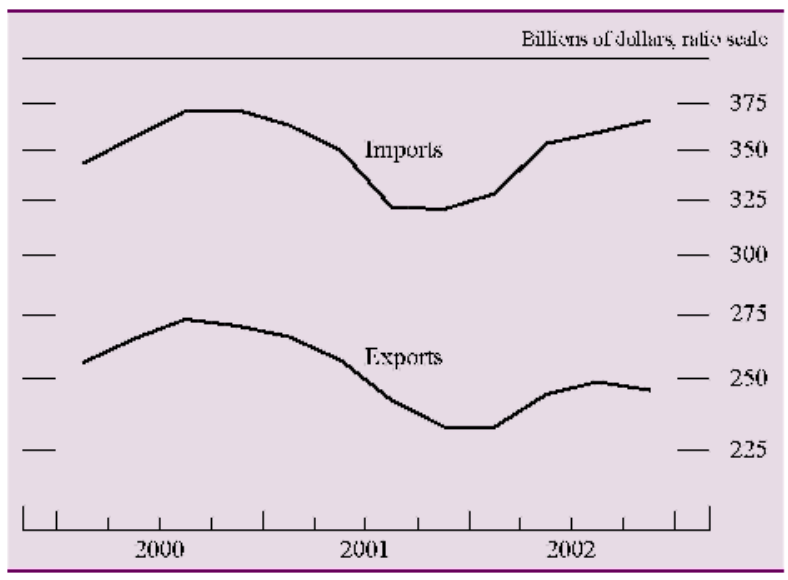

NOTE. The data are quarterly and seasonally adjusted.

SOURCE. BEA.

the year, these receipts actually grew about 5 percent between the fourth quarter of 2001 and the fourth quarter of 2002 (table 3). Similarly, nominal imports of goods and services rose much more rapidly on a Q4-to-Q4 basis (14 percent) than they did on a yearover-year basis (4 percent).

4. Change in the quantity of U.S. exports and imports of goods and services, 1999-2002

Percent change from fourth quarter to fourth quarter

\begin{tabular}{|c|c|c|c|c|}
\hline Item & 1999 & 2000 & 2001 & 2002 \\
\hline Exports & 5 & 7 & -11 & 4 \\
\hline $\begin{array}{l}\text { Services } \\
\text { Goods .... }\end{array}$ & $\begin{array}{l}3 \\
6\end{array}$ & $\begin{array}{l}5 \\
8\end{array}$ & $\begin{array}{r}-9 \\
-12\end{array}$ & $\begin{array}{r}11 \\
1\end{array}$ \\
\hline $\begin{array}{l}\text { Capital equipment }{ }^{1} \ldots \ldots \ldots \ldots \ldots \\
\text { Aircraft and parts } \ldots \ldots \ldots \ldots \ldots \\
\text { Computer equipment }{ }^{2} \ldots \ldots \ldots \ldots \ldots \ldots \\
\text { Semiconductors } \ldots \ldots \ldots \ldots \ldots \ldots \\
\text { Other machinery and equipment }\end{array}$ & $\begin{array}{r}7 \\
-17 \\
13 \\
34 \\
8\end{array}$ & $\begin{array}{r}13 \\
-14 \\
23 \\
27 \\
14\end{array}$ & $\begin{array}{l}-21 \\
-4 \\
-24 \\
-35 \\
-20\end{array}$ & $\begin{array}{r}-1 \\
-3 \\
-2 \\
8 \\
-2\end{array}$ \\
\hline 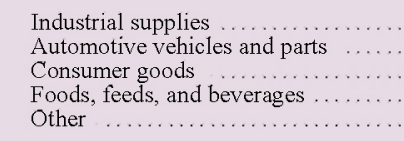 & $\begin{array}{r}7 \\
3 \\
5 \\
3 \\
-1\end{array}$ & $\begin{array}{l}7 \\
1 \\
6 \\
3 \\
6\end{array}$ & $\begin{array}{r}-7 \\
-5 \\
-6 \\
5 \\
-6\end{array}$ & $\begin{array}{r}3 \\
3 \\
2 \\
-6 \\
5\end{array}$ \\
\hline Imports & 12 & 11 & -8 & 10 \\
\hline $\begin{array}{l}\text { Services } \ldots \\
\text { Goods } \ldots\end{array}$ & $\begin{array}{r}6 \\
13\end{array}$ & $\begin{array}{l}11 \\
11\end{array}$ & $\begin{array}{l}-9 \\
-8\end{array}$ & $\begin{array}{l}12 \\
10\end{array}$ \\
\hline $\begin{array}{l}\text { O1l } \\
\text { Non-oil . }\end{array}$ & $\begin{array}{l}-3 \\
15\end{array}$ & $\begin{array}{l}13 \\
11\end{array}$ & $\begin{array}{r}0 \\
-9\end{array}$ & $\begin{array}{r}4 \\
10\end{array}$ \\
\hline $\begin{array}{l}\text { Capital equipment }{ }^{1} \ldots \ldots \ldots \ldots \ldots \\
\text { Aircraft and parts } \ldots \ldots \ldots \ldots \ldots \\
\text { Computer equipment }{ }^{2} \ldots \ldots \ldots \ldots \\
\text { Semiconductors } \ldots \ldots \ldots \ldots \ldots \ldots \\
\text { Other machinery and equipment }\end{array}$ & $\begin{array}{l}19 \\
-2 \\
26 \\
34 \\
15\end{array}$ & $\begin{array}{l}17 \\
22 \\
14 \\
23 \\
17\end{array}$ & $\begin{array}{r}-21 \\
3 \\
-14 \\
-51 \\
-21\end{array}$ & $\begin{array}{r}7 \\
-20 \\
14 \\
9 \\
10\end{array}$ \\
\hline $\begin{array}{l}\text { Industrial supplies ............ } \\
\text { Automotive vehicles and parts } \\
\text { Consumer goods ............. } \\
\text { Foods, feeds, and beverages } \\
\text { Other }\end{array}$ & $\begin{array}{r}8 \\
14 \\
17 \\
11 \\
5\end{array}$ & $\begin{array}{r}1 \\
2 \\
16 \\
6 \\
16\end{array}$ & $\begin{array}{r}-5 \\
-2 \\
-5 \\
5 \\
0\end{array}$ & $\begin{array}{r}8 \\
10 \\
17 \\
6 \\
5\end{array}$ \\
\hline
\end{tabular}

Note. Quantities are measured in chained (1996) dollars.

1 Data for telecommunications equipment not separately calculated.

2. Computers, accessories, peripherals, and parts.

Source. BEA, national income and product accounts; Federal Reserve Board.
Measured both in terms of nominal values (table 3) and quantities (table 4), imports rose faster than exports between the fourth quarter of 2001 and the fourth quarter of 2002. Imports grew faster than exports despite the fact that real GDP here and abroad grew at about the same rate last year. This development is consistent, however, with a historical pattern in which the responsiveness of U.S. imports to income in the United States has been greater than the responsiveness of U.S. exports to income in the rest of the world. Moreover, because capital goods constitute a greater fraction of U.S. exports than they do of U.S. imports, the weakness in investment spending both here and abroad last year weighed more heavily on exports than on imports. Finally, although the dollar depreciated last year, the lagged effects of its earlier appreciation continued to support imports while restraining exports.

\section{Exports}

The 5 percent rise in the nominal value of exported goods and services between the fourth quarter of 2001 and the fourth quarter of 2002 reflects much stronger growth in exports of services than of goods. Services receipts rose 14 percent over this period after having declined sharply in 2001; much of the rebound was in receipts from foreign travelers in the United States, which recovered somewhat in 2002 following a plunge immediately after the September 11 terrorist attacks. Receipts from foreigners for other services moved up smartly as well.

In contrast, nominal exports of goods rose only 2 percent in 2002 (Q4 to Q4); they were held back by a 1 percent decline in export sales of capital goods. This slowing likely reflected the pronounced weakness of investment spending during the recent global slowdown, even as consumption spending held up more strongly. Especially large percentage declines in exports of computer and telecommunication equipment were consistent with continued weakness in the high-tech sector (as well as trend declines in computer prices), while the slight rise in exports of semiconductors reversed very little of their pronounced decline in 2001.

Outside of the capital goods sector, exports of industrial supplies grew substantially over the course of 2002, but most of this increase reflected higher prices rather than a sharp pick-up in quantities. Exports of automotive products also showed some strength; the increase was more than accounted for by higher shipments of vehicles and parts to Canada. The relatively flat dollar-value of sales of food, feed, 
5. Distribution of U.S. exports of goods, by selected regions and countries, 2000-2002 Billions of dollars except as noted

\begin{tabular}{|c|c|c|c|c|c|}
\hline \multirow[b]{2}{*}{ Destination } & \multirow[b]{2}{*}{2000} & \multirow[b]{2}{*}{2001} & \multirow[b]{2}{*}{2002} & \multicolumn{2}{|c|}{$2001-02$} \\
\hline & & & & Change & $\begin{array}{l}\text { Percent } \\
\text { change, } \\
\text { Q4 to Q4 }\end{array}$ \\
\hline All & 772 & 719 & 683 & -36.2 & 2.0 \\
\hline Western Europe & 179 & 171 & 154 & -17.8 & -1.8 \\
\hline Canada & 179 & 163 & 161 & -2.4 & 6.2 \\
\hline Latin America & 170 & 159 & 148 & -10.6 & -6 \\
\hline Mexico & 111 & 101 & 97 & -3.8 & 1.1 \\
\hline Other & 59 & 58 & 51 & -6.8 & -3.6 \\
\hline Asia & 194 & 173 & 167 & -5.6 & 3.3 \\
\hline Japan & 63 & 56 & 50 & -6.2 & -2.3 \\
\hline Emerging markets ${ }^{1}$ & 130 & 117 & 118 & .6 & 5.8 \\
\hline Other & 50 & 52 & 52 & 3 & 4.8 \\
\hline
\end{tabular}

1. China, Hong Kong, Indonesia, Korea, Malaysia, Philippines, Singapore, Taiwan, and Thailand.

SoURCE. BEA, U.S. international transactions accounts.

and beverages abroad reflected the offsetting effects of a sharp contraction in exported quantities of these products, in part resulting from poor harvests, and corresponding increases in their prices.

The distribution of U.S. sales of goods to different parts of the world in 2002 (table 5) was substantially influenced by the economic performance of our trading partners. Exports of goods to those regions showing the strongest performance last year - Canada, the Asian emerging-market economies, and Mexicomoved up on a Q4-to-Q4 basis, while sales to weaker economies - those of western Europe, Japan, and South America-declined. The rise over the course of 2002 in sales to Canada, which account for nearly a quarter of U.S. goods exports, was primarily accounted for by automotive products, industrial supplies, and consumer goods and was driven by strong household spending. Capital goods, which represent the largest end-use category of sales to Canada, remained about flat. Exports to the Asian emergingmarket economies were boosted primarily by higher sales of industrial supplies (especially chemicals) and capital goods. In both western Europe and Japan, where economic activity has continued to be restrained by weak business investment, mild declines in U.S. goods exports resulted almost entirely from reductions in sales of capital goods.

The quantity of exports rose 4 percent in 2002 (Q4 to Q4) after declining sharply the previous year (table 4). As with movements in their value, the quantity of exported services rose considerably faster than that of goods. Exports of all major categories rose except for foods, feeds, and beverages, which declined markedly, and capital equipment.
6. Change in the prices of U.S. exports and imports of goods and services, 1999-2002

Percent change from fourth quarter to fourth quarter

\begin{tabular}{|c|c|c|c|c|}
\hline Item & 1999 & 2000 & 2001 & 2002 \\
\hline Exports $\ldots$. & 0 & 1 & -2 & 2 \\
\hline Services & 1 & 2 & -2 & 2 \\
\hline Goods $\ldots$. & 0 & 1 & -2 & 1 \\
\hline Capital equipment & -1 & 0 & -1 & -1 \\
\hline Aircraft and parts & 2 & 5 & 5 & 3 \\
\hline Computer equipment & -7 & -4 & -4 & -5 \\
\hline Semiconductors ..... & -4 & -5 & -6 & -3 \\
\hline Other machinery and equipment & 0 & 1 & 0 & 0 \\
\hline Industrial supplies & 4 & 4 & -7 & 5 \\
\hline Automotive vehicles and parts $\quad . . \ldots \ldots$ & 1 & 1 & 0 & 1 \\
\hline Consumer goods & 0 & 0 & 0 & -1 \\
\hline Foods, feeds, and beverages & -4 & 0 & -1 & 7 \\
\hline Other $\ldots \ldots \ldots \ldots \ldots \ldots$ & 1 & 1 & -2 & 2 \\
\hline Imports & 3 & 3 & -5 & 4 \\
\hline Services & 0 & 3 & 3 & 7 \\
\hline Goods & 4 & 3 & -7 & 3 \\
\hline $\mathrm{O}_{1}$ & 94 & 31 & -36 & 40 \\
\hline Non-oil & -1 & 1 & -4 & 0 \\
\hline Capital equipment & -4 & -2 & -3 & -2 \\
\hline Aircraft and parts & 2 & 4 & 3 & 2 \\
\hline Computer equipment .............. & -11 & -5 & -12 & -4 \\
\hline Semiconductors $\ldots$ & -3 & -2 & -3 & -3 \\
\hline Other machinery and equipment ... & -1 & -1 & -1 & -2 \\
\hline Industrial supplies & 4 & 11 & -13 & 4 \\
\hline Automotive vehicles and parts & 1 & 1 & 0 & 0 \\
\hline 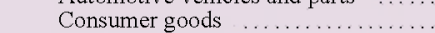 & -1 & -1 & -1 & -1 \\
\hline Foods, feeds, and beverages ........ & -3 & -2 & -3 & 4 \\
\hline 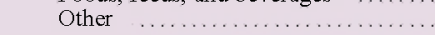 & 0 & 1 & -2 & 1 \\
\hline
\end{tabular}

Note. Price indexes are chain-weighted. See also notes to table 4.

After declining in 2001 in response to the slowdown in global growth, export prices rose 2 percent last year (Q4 to Q4, table 6); they were boosted by higher global growth, an associated firming of commodity prices (including petroleum prices), and perhaps some effects from the weakening dollar. Services prices recovered as demand for travel moved back up from lows reached after the events of September 11, 2001. Weather-related supply disruptions drove up prices of foods, feeds, and beverages 7 percent, while higher costs of petroleum products, natural gas, lumber, and steel led to a 5 percent rise in prices of industrial supplies. Prices of exported capital equipment edged down again last year and reflected trend declines in the prices of computers and semiconductors.

\section{Imports}

The value of imports rose 14 percent from the fourth quarter of 2001 to the fourth quarter of 2002 (table 3), though this gain in part reflects a bounce-back from the depressed levels reached in the aftermath of September 11, 2001. Services, rebounding especially quickly, rose 19 percent over the same period. As on 
the exports side, a surge in travel-related spending by U.S. residents abroad following the lows reached after September 11, 2001, accounted for much of this increase, although other types of services rose as well. Imports of goods also rose briskly over the course of last year, with increases on a Q4-to-Q4 basis registered for both the oil and non-oil categories.

\section{Oil Imports}

The value of oil imports rose 46 percent from the fourth quarter of 2001 to the fourth quarter of 2002 (table 3 ). This sharp rise primarily reflected a 40 percent rebound in the price of imported oil last year from its low level at the end of 2001. Additionally, the pickup in U.S. economic growth in 2002 led to a small rise in the quantity of oil imports on a Q4-to-Q4 basis; the quantity of oil imports was also boosted by some bounce-back from unusually depressed levels immediately after September 11, 2001, when travel fell off sharply. With domestic oil consumption last year exceeding the sum of imported and domestically produced oil, oil inventories declined.

\section{Non-oil Imports}

The quantity of non-oil imports rose 10 percent in 2002 (Q4 to Q4, table 4), reversing a decline of similar magnitude in the previous year. Reflecting the consumer-led nature of U.S. real GDP growth last year, increases were led by double-digit gains in real imports of automotive products and consumer goods. Imports of industrial supplies and capital equipment rose more moderately, with the latter being held back by a 20 percent decline in imports of aircraft and parts, which are quite volatile. Imports of both computer equipment and semiconductors bounced back in 2002 after sharp declines the previous year, but increases in the larger "Other machinery and equipment" category were more moderate and were well below the pace of the previous year's decline.

Several factors contributed to the substantial growth in the quantity of non-oil imports last year, which considerably outpaced the rise in U.S. GDP. First, as noted above, imports were unusually depressed in the fourth quarter of 2001 , so some of the subsequent growth reflected a return to more normal levels. Second, U.S. non-oil imports, and tradable goods in general, are particularly cyclically sensitive. This sensitivity may result from the fact that the demand for goods tends to fluctuate over the course of the business cycle more than does the demand for services and hence more than does GDP as a whole; therefore, non-oil goods imports are also likely to fluctuate more widely than total GDP. To illustrate, the quantity of non-oil imports declined 9 percent in 2001 (Q4 to Q4), when U.S. activity had slowed but did not decline; non-oil imports then rose 10 percent in 2002, when U.S. growth picked up to only about 3 percent. ${ }^{2}$ Third, as noted earlier, over long periods of time, U.S. imports have tended to grow more rapidly than U.S. GDP (even as exports have grown more in line with the GDP of U.S. trading partners). Finally, imports were likely buoyed by the value of the dollar, which remained quite strong by historical standards, notwithstanding some declines over the course of the year.

Prices of non-oil imports were flat last year after falling 4 percent in 2001 (table 6). Higher commodity prices, as well as the effects of the fall in the dollar later in the year, led to notable increases in the prices of imported industrial supplies and foods, feeds, and beverages. However, prices of computers and semiconductors extended their persistent declines, while still-weak demand in global manufacturing likely contributed to further declines in the prices of other machinery and equipment as well as consumer goods. A brisk 7 percent rise in services prices last year probably reflected the decline in the dollar.

\section{DEVELOPMENTS IN THE NONTRADE CURRENT ACCOUNT}

The major components of the current account other than trade in goods and services are investment income and unilateral transfers.

\section{Investment Income}

Net investment income is the difference between the income that U.S. residents earn on their holdings of foreign assets (receipts) and the income that foreigners earn on their holdings of U.S. assets (payments). If the rates of return on both of these holdings were equal, then movements in net investment income

2. Analogously, the quantity of U.S. goods exports declined 12 percent from the fourth quarter of 2000 to the fourth quarter of 2001 . when foreign growth declined to about zero. With foreign growth having recovered to nearly 3 percent in 2002, however, it is not clear why the growth of real goods exports rose only to 1 percent. This slow growth reflected an anomalous decline in December that was partially reversed in January 2003. 
6. U.S. net international investment: Position and income, 1980-2002

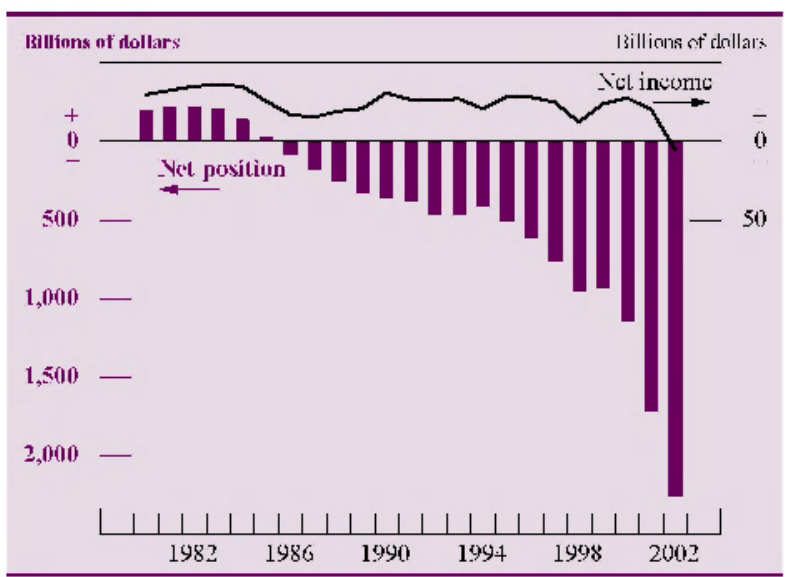

NoTE. The data are annual. The net position is the average of the year-end positions for the current and previous years. The year-end position for 2002 was constructed by adding the recorded portfolio investment flows during 2002 to the recorded year-end position for 2001 . The net position excludes U.S. holdings of gold.

SOURCE. BE A; Federal Reserve Board.

would exactly mirror movements in the net international investment position, that is, the difference between U.S. holdings of foreign assets and foreign holdings of U.S. assets. The net international investment position turned negative in 1986 and has declined progressively further since then as large net financial inflows have financed the United States' current account deficits (chart 6). Even as foreign acquisition of U.S. assets has substantially outpaced U.S. acquisition of foreign assets, however, net investment income remained positive until 2002 (table 7), as rates of return on U.S. holdings abroadprimarily through direct investments - have exceeded returns on foreign holdings in the United States.

\section{Direct Investment Income}

Net direct investment income - receipts from U.S. direct investment abroad less payments on foreign
7. U.S. direct investment abroad:

Position and receipts, 1980-2002

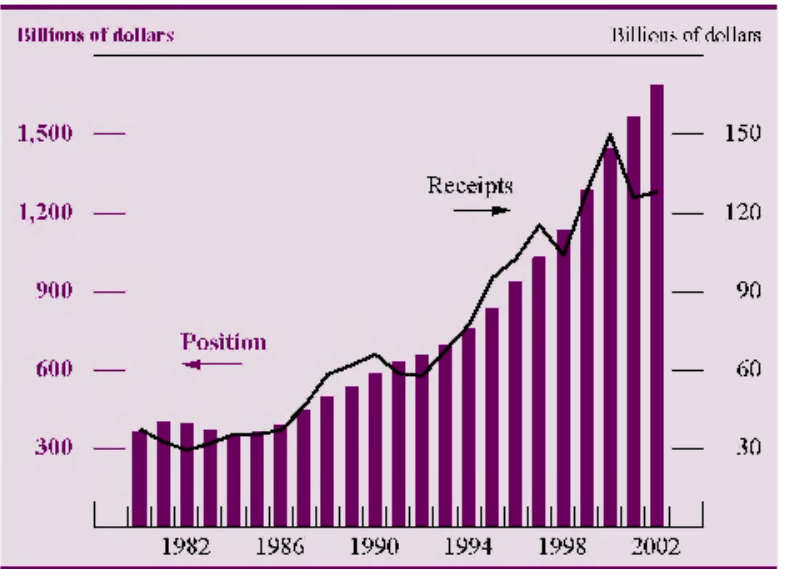

Note. The data are annual. The position is the average of the year-end current-cost measures for the current and previous years. The year-end position for 2002 was constructed by adding the recorded direct investment capital flows and current-cost adjustment during 2002 to the recorded year-end position for 2001 .

SOURCE. BEA; Federal Reserve Board.

direct investment in the United States - declined $\$ 25$ billion in 2002 , to $\$ 78$ billion (table 7 ). A small increase in direct investment receipts was outweighed by a much larger rise in payments last year.

The $\$ 2$ billion pickup in receipts on U.S. direct investment abroad last year was relatively meager, considering that the U.S. gross direct investment position abroad rose roughly $\$ 100$ billion (chart 7) and that total foreign growth rebounded after stagnating in 2001. However, profits are likely to be related more to the level of capacity utilization than to the growth of real GDP as such. Foreign growth picked up last year but probably not enough to substantially increase resource utilization and profits. Moreover, more than half of U.S. direct investment is in Europe, where growth remained low relative to that in the United States or other U.S. trading partners. All of these factors likely held back the growth of receipts on U.S. direct investment abroad last year.

7. U.S. international investment: Receipts and payments, 1998-2002

Billions of dollars

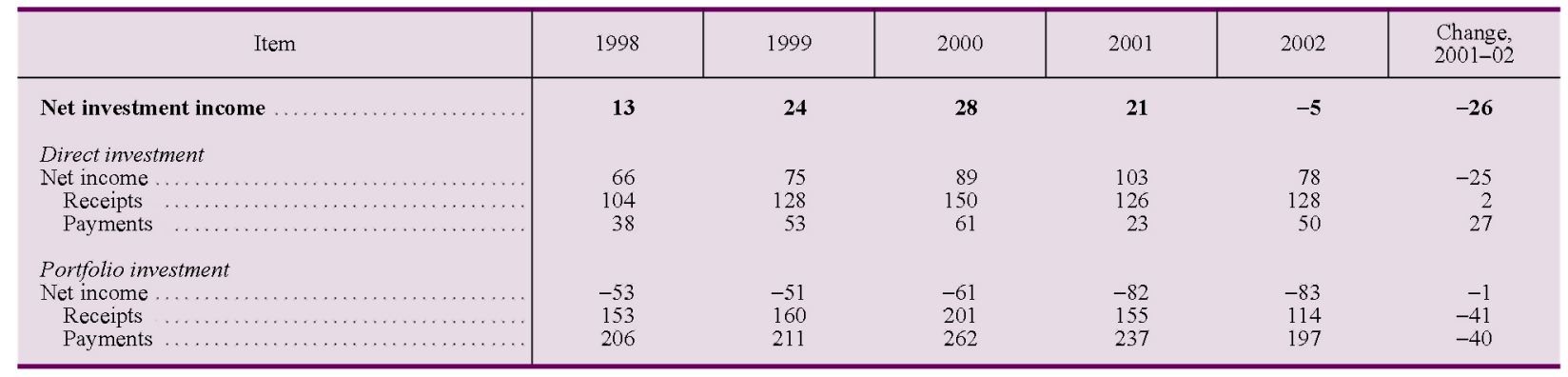

SOURCE. BEA, U.S. international transactions accounts. 
8. Foreign direct investment in the United States: Position and payments, 1980-2002

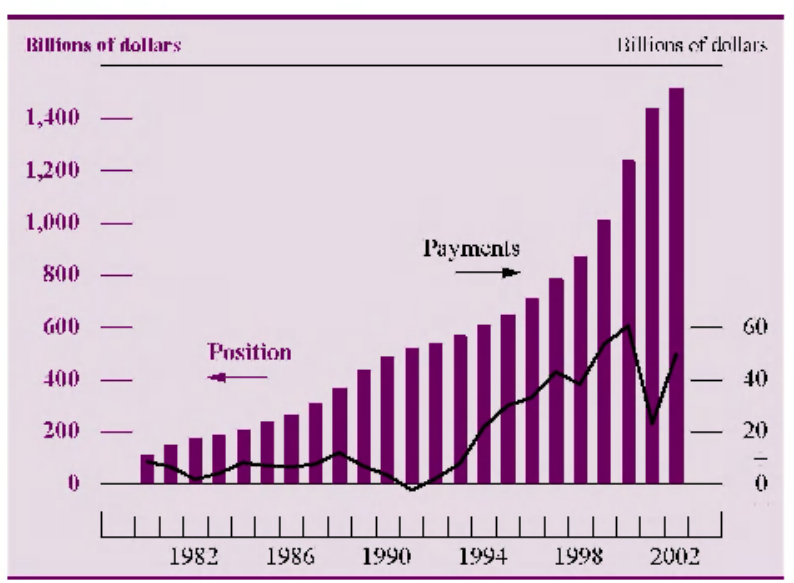

NOTE. See notes to chart 7 .

In contrast to receipts, payments rose a substantial $\$ 27$ billion last year, bouncing back after a $\$ 38$ billion decline in 2001. A small increase in foreign direct investment holdings in the United States (chart 8) explains some of the increase in payments. More importantly, increases in the profitability of foreign investments in the U.S. last year followed abnormally low levels in 2001 and helped to boost payments. The recovery in these profits was widespread, but the industries that fell most sharply in 2001-manufacturing and wholesale trade-showed the largest growth in 2002.

\section{Portfolio Investment Income}

Portfolio receipts represent the dividend and interest income that U.S. residents receive on their holdings of foreign financial assets, whereas portfolio payments represent the dividends and interest that foreigners receive on their holdings of U.S. financial assets. The Bureau of Economic Analysis (BEA) estimates these payments and receipts by applying estimates of the interest or dividend-payout rates for various assets to estimates of the holdings of those assets. Portfolio investment income does not include capital gains or losses associated with changes in asset prices.

Movements in net portfolio income-receipts minus payments - have tracked movements in the U.S. net portfolio investment position fairly closely (chart 9) because rates of return on portfolio investments in the United States and abroad are quite similar (chart 10). Net portfolio income turned negative in 1985 , the same year that the net portfolio investment position moved from that of net creditor
9. Net portfolio investment: Position and income, 1980-2002

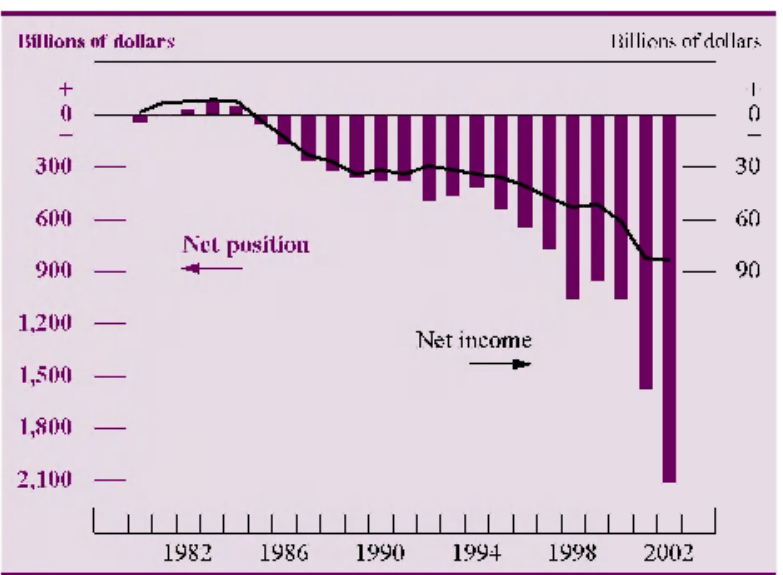

NoTE. The data are annual. The net position is the Federal Reserve Board's estimate of the average position during the year. Through 2001 these estimates are based on quarterly financial flows and year-end position estimates published by the BEA. For 2002, the average is based on year-end 2001 position data and quarterly financial flows during 2002. The net position excludes U.S. gold holdings and foreign holdings of U.S. currency.

SOURCE. BEA; Federal Reserve Board.

to net debtor, and it followed the general contour of the net investment position in subsequent years. More recently, however, declines in interest rates have tended to reduce both payments and receipts, thereby leading the deficit in portfolio income to widen more slowly than it would have otherwise. This effect was particularly pronounced last year, when the negative net income balance widened only $\$ 1$ billion, to $\$ 83$ billion.

\section{Unilateral Transfers}

Unilateral transfers include government grant and pension payments as well as private transfers to and

10. Rate of return on U.S. portfolio investments, 1980-2002

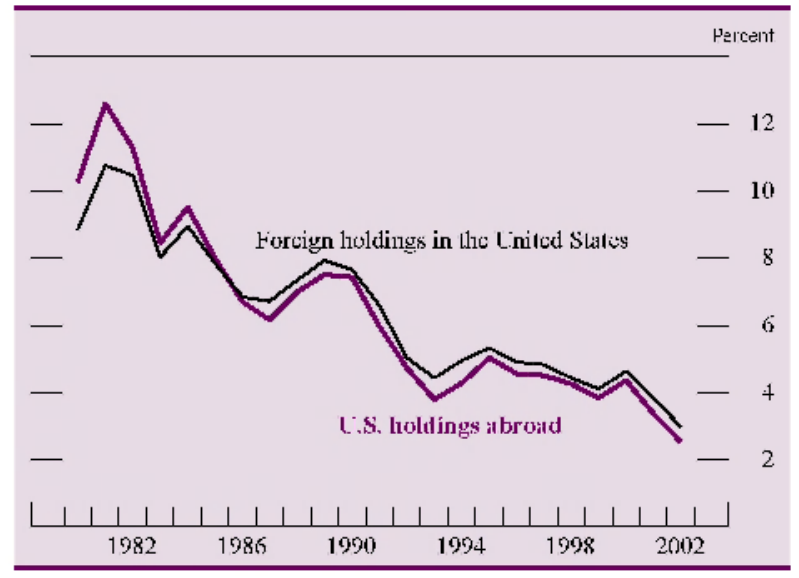

NoTE. The data are annual. 
from foreigners. In 2002, the deficit on net unilateral transfers widened to $\$ 56$ billion.

\section{FINANCIAL AND CAPITAL ACCOUNT. TRANSACTIONS.}

The counterpart of the increased U.S. current account deficit last year was a rise in net financial inflows of foreign savings. In recent years, net private capital inflows have accounted for most of the overall net inflows required to finance the current account deficit, and 2002 was no exception. However, even as the current account deficit rose to a record $\$ 503$ billion last year, net private capital inflows remained about unchanged at $\$ 381$ billion, while net official inflows jumped to $\$ 93$ billion (table 8 ).

A prominent theme in last year's capital flows was the reduced demand by private foreign entities for U.S. corporate assets. Private foreign net purchases of all U.S. securities declined $\$ 62$ billion in 2002. Net purchases of U.S. corporate and other bonds and of corporate stocks fell $\$ 41$ billion and $\$ 63$ billion respectively. These declines were only partially offset by a positive $\$ 43$ billion swing of flows into U.S. Treasury and agency securities; these flows appear to have been driven by a flight to safety among investors. Private foreign direct investment in the United States also fell off substantially, from $\$ 131$ billion in 2001 to $\$ 30$ billion in 2002 .

The decline in the demand for claims on the U.S. private sector last year may have been associated with increased concerns about future profitability and returns; these concerns were perhaps prompted by the uneven recovery of the U.S. economy and the continued poor performance of equity markets. Similar concerns may have prompted an analogous pullback of U.S. investments abroad. Private U.S. net purchases of foreign securities plummeted from $\$ 95$ billion in 2001 to about zero last year. This drop reflected net sales of foreign bonds by U.S. private investors for the second consecutive year as well as sharply reduced purchases of foreign stocks. U.S. direct investment abroad held up, but that was due to U.S. corporations not repatriating earnings and extending more credit to their foreign affiliates; new equity capital channeled toward direct investment abroad fell from $\$ 50$ billion in 2001 to $\$ 27$ billion last year.

With private foreign purchases of U.S. assets falling about as much as private U.S. purchases of

8. Composition of U.S. capital flows, 1997-2002

Billions of dollars

\begin{tabular}{|c|c|c|c|c|c|c|c|c|}
\hline \multirow{2}{*}{ Item } & \multirow{2}{*}{1997} & \multirow{2}{*}{1998} & \multirow{2}{*}{1999} & \multirow{2}{*}{2000} & \multirow{2}{*}{2001} & \multirow{2}{*}{2002} & \multicolumn{2}{|c|}{2002} \\
\hline & & & & & & & $\mathrm{H} 1$ & $\mathrm{H} 2$ \\
\hline Current account balance .... & -128 & -204 & -293 & -410 & -393 & -503 & -240 & -263 \\
\hline Capital account balance & $\mathbf{0}$ & 1 & -3 & 1 & 1 & 1 & 0 & 0 \\
\hline Financial account balance & 219 & 64 & 265 & 409 & 382 & 474 & 160 & 314 \\
\hline Official capital, net ...... & 18 & -27 & 55 & 36 & 0 & 93 & 54 & 40 \\
\hline Foreign official assets in the United States & 19 & -20 & 44 & 38 & 5 & 97 & 55 & 42 \\
\hline U.S. official reserve assets ............ & -1 & -7 & 9 & 0 & -5 & -4 & -1 & -2 \\
\hline Other U.S. government assets & 0 & 0 & 3 & -1 & 0 & 0 & 0 & 0 \\
\hline Private capital, net & 201 & 91 & 210 & 373 & 382 & 381 & 107 & 274 \\
\hline Net inflows reported by U.S. banking offices & 8 & 4 & -22 & -32 & -18 & 92 & -47 & 138 \\
\hline Securities transactions, net ..................... & 173 & 49 & 126 & 251 & 305 & 340 & 155 & 185 \\
\hline Private foreign net purchases ( + ) of U.S. securities & 292 & 185 & 254 & 378 & 400 & 338 & 163 & 175 \\
\hline Treasury securities $\ldots \ldots \ldots \ldots \ldots \ldots \ldots \ldots$ & 130 & 29 & -44 & -77 & -8 & 53 & -12 & 66 \\
\hline Agency bonds ............ & 26 & 5 & 43 & 96 & 86 & 68 & 35 & 33 \\
\hline Corporate and other bonds & 67 & 106 & 143 & 166 & 202 & 161 & 104 & 57 \\
\hline Corporate stocks $\ldots . . .$. . & 69 & 46 & 113 & 192 & 119 & 56 & 36 & 19 \\
\hline U.S. net purchases (-) of foreign securities & -119 & -136 & -128 & -128 & -95 & 2 & -8 & 10 \\
\hline 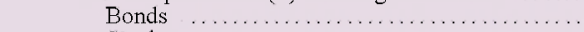 & -61 & -35 & -14 & -24 & 12 & 21 & 11 & 10 \\
\hline Stocks ......... & -58 & -101 & -114 & -104 & -107 & -19 & -18 & 0 \\
\hline Stock swaps & -3 & -96 & -123 & -80 & -45 & -3 & -2 & -1 \\
\hline Direct investment, net ........... & 1 & 36 & 101 & 129 & 3 & -93 & -50 & -43 \\
\hline Foreign direct investment in the United States & 106 & 179 & 289 & 308 & 131 & 30 & 14 & 16 \\
\hline U.S. direct investment abroad ................. & -105 & -143 & -189 & -178 & -128 & -124 & -64 & -59 \\
\hline Foreign holdings of U.S. currency & 25 & 17 & 22 & 1 & 24 & 22 & 12 & 10 \\
\hline Other & -5 & -15 & -17 & 23 & 68 & 21 & 37 & -16 \\
\hline Statistical discrepancy & -91 & 139 & 31 & 0 & 11 & 29 & 79 & -51 \\
\hline
\end{tabular}

SouRCE. BEA, U.S. international transactions accounts 
foreign assets, private net capital flows were about unchanged last year, even as the current account deficit rose $\$ 110$ billion. Most of this shortfall in private financing was made up by a substantial rise in official net capital inflows to $\$ 93$ billion, with nearly all of the remaining shortfall showing up in the statistical discrepancy. The higher pace of these acquisitions last year may have reflected the desire of some foreign authorities to restrain the rise in their currencies' value against the dollar by intervening in foreign exchange markets. This explanation is suggested by the concentration of foreign official inflows in the second and fourth quarters of last year, when the foreign exchange value of the dollar registered its largest declines.

Capital account transactions, which consist mainly of debt forgiveness and wealth transfers associated with immigration, netted to $\$ 1$ billion last year, the same amount as in the previous two years.

\section{PROSPECTS FOR 2003}

Forecasters generally expect that rates of economic growth will pick up both in the United States and in its major trading partners later this year and in 2004. Assuming this acceleration of activity takes place as expected, the U.S. external deficit likely will widen as U.S. imports of goods and services rise by a greater amount than U.S. exports of goods and services. The decline in the dollar that has been observed from early 2002 to date is unlikely to restrain the widening of the deficit by much, as it has been relatively small-about 5 percent for the broad real dollar index-and its effects will be spread over a number of years. In fact, the initial effect of a depreciation of the dollar is generally to raise the U.S. current account deficit temporarily, since it raises import prices, and hence the value of imports, more rapidly than it stimulates sales of exports. 